\title{
Methodology for assessing the investment component of the region's financial and budgetary security (case study of the Komi Republic)
}

\author{
Elena Karanina*, and Mihail Kyzyurov \\ Vyatka State University, Moskovskaya St., 36, 610000 Kirov, Russia
}

\begin{abstract}
The purpose of the study is to analyze the existing methodological approaches to assessing the investment component of financial and budgetary security and to develop, on their basis, a methodology for assessing the investment security of a region. In the course of the study, methods such as indicative method, comparison method, analysis, synthesis were used. The article provides a brief description of approaches to assessment of investment security and the author's methodology for assessing the investment component of the financial and budgetary security of the regions. In addition, the article presents the author's list of indicators, with the help of which it is proposed to assess, diagnose and identify threats that pose a threat to the financial and budgetary sphere. The proposed methodology has been tested on the example of the Komi Republic.
\end{abstract}

\section{Introduction}

Financial and budgetary security is a key component of the economic security of the region on the state of which the functioning of the entire economy of a constituent entity of the Russian Federation depends. Finance for the economy is a circulatory system that supplies the state or region with the financial resources necessary for the normal functioning and development. The well-being of all participants in economic relations, from the state to small enterprises and households, depends on how effectively the mechanism for ensuring financial and budgetary security operates.

The financial security of the region includes a number of elements that form an integral security system. Among such elements it is necessary to highlight the follows: budgetary, tax, inflationary-price, investment, corporate-financial, foreign economic security and also the security of the banking sector, financial security of the population. Each of these structural elements is closely interconnected with the others and together they form an integral system of financial budgetary security. That is such a state of the financial system of the region in which due to the availability of the necessary financial resources and competent actions of the state authorities and the constituent entity of Russia and local governments ensured its progressive development, integrity and unity, stability, resistance to the impact of 
internal and external threats, balance, protection of the interests of all participants in financial relations within the region, competitiveness, independence and efficiency.

Financial and budgetary security includes a number of components among which investment security is of particular importance for the development of the region's economy. An essential element of economic security is investment security.

Investment security of the region is the state of the investment system which ensures guaranteed protection of the economic system of the region, satisfaction of current investment needs both in structure and in volume, taking into account the effective use and return of invested funds in order to develop the regional economy [1]. Investments act as a catalyst to provide conditions for the development of the country and region to overcome crisis factors and economic security threats $[2 ; 3]$. Investments also play a huge role in the regional economy due to the fact that they are the basis for the reproduction of fixed assets of enterprises operating in the regions, the expansion and growth of production, contribute to the development of new types of activities are a factor on which the region's income and gross regional product directly depend. High investment activity contributes to the economic growth of the region, the creation of additional jobs, an increase in the level of employment of the population of the region constitute a necessary condition for its development. In the Strategy of Economic Security of the Russian Federation until 2030, "insufficient investment in the real sector of the economy due to an unfavorable investment climate, high business costs, excessive administrative barriers, and ineffective protection of property rights" is named as one of the main threats to economic security.

Investment activity has a direct impact on the solution of many socio-economic problems and also on the economic development of the region. The economic meaning of the investment activity of the state, region, and enterprise is made up of investments in the creation of new objects of entrepreneurial activity, in renovation and modernization, as well as technical re-equipment of existing enterprises.

Thus, the decline in the investment attractiveness of the region is one of the most important threats to the financial and budgetary security of the constituent entity of the Russian Federation.

The stable state of the financial and budgetary system of the regions is ensured by how effectively the mechanism for ensuring financial and budgetary security operates, which includes a set of various tools, procedures, management decisions, regulatory legal acts, means, measures and methods used by the state to prevent the emergence and neutralization of negative consequences of the action of threats to the financial and budgetary security of the region, ensuring its progressive economic development.

\section{Materials and Methods}

One of the most important elements of the mechanism for ensuring financial and budgetary security in general and investment security in particular is monitoring the state of the financial and budgetary sphere whose tasks include identifying, predicting and preventing threats to financial and budgetary security at an early stage of their development. Monitoring financial and budgetary security, in our opinion, is of paramount importance for maintaining the stability and stability of the region's economy, it shows the current state of the financial and budgetary system and allows you to determine the trends of changes in the economy.

There are various approaches to assessing fiscal security. Among the foundations governmental methods for assessing fiscal security of the region should be highlighted the follows:

1) Indicative method which involves comparing the values of indicators by region with the developed threshold values; 
2) Assessment of the rate of economic growth of the region based on the main macroeconomic and integral indicators;

3) An expert method for ranking regions by threats;

4) Quantitative assessment of the damage caused to the security object;

5) Methods of applied mathematics which include multivariate statistical analysis, probability theory, regression and correlation analysis which provide data with a high level of reliability but require a lot of time to process them and carry out fairly complex operations;

6) financial and budgetary control [4].

In our opinion, the most preferable method is the indicative one as in the case of a competent selection of indicators and their threshold values it allows us to diagnose existing threats to the safe state of the region in the most accurate way. Also, an undoubted advantage of the approach is its ease of use in comparison with the methods of applied mathematics, and in comparison with the expert method the assessment of investment security is more objective, as in the process of its implementation statistical data are analyzed that excludes the possibility of making mistakes during monitoring. [5].

In the scientific literature there are various approaches to the formation of indicators of the investment security of the region, table 1 presents the most interesting of them.

Table 1. Approaches to the formation of investment security indicators $[6 ; 7 ; 8 ; 9 ; 10 ; 11 ; 12 ; 13 ; 14]$

\begin{tabular}{|c|c|}
\hline Author & Feature Description \\
\hline N.K. Ismailova & $\begin{array}{l}\text { The assessment of the investment security of the region is carried out } \\
\text { using the indicative method, which consists in comparing the } \\
\text { indicators for the region with the threshold values. Indicators of } \\
\text { investment security include the follows: the volume of foreign } \\
\text { investment to GDP, the share of foreign investment in the banking } \\
\text { sector, investment in fixed assets, the amount of external debt[8]. }\end{array}$ \\
\hline D. Loginov, E. Karanina & $\begin{array}{l}\text { Indicators: the volume of investments in fixed assets, the rate of } \\
\text { growth (decrease) in the volume of investments in fixed assets [9]. }\end{array}$ \\
\hline $\begin{array}{l}\text { L. Karpenko, O. } \\
\text { Ignatenko, O. Taranenko, } \\
\text { I. Oliinyk, R. Khrenova- } \\
\text { Shymkina }\end{array}$ & $\begin{array}{l}\text { The main indicator for assessing investment security: the share of } \\
\text { investment accumulation in GRP [10]. }\end{array}$ \\
\hline $\begin{array}{ll}\text { M.G Nikitina, } & \text { V.V. } \\
\text { Pobirchenko, } & \text { E.A. } \\
\text { Shutaieva, A.I. Karlova }\end{array}$ & $\begin{array}{l}\text { The authors use an indicative method and a ranking method. } \\
\text { Investment security is assessed using indicators: investment in the } \\
\text { economy, \%, inflow of foreign investment in the economy, \%, outflow } \\
\text { of investment from the economy, \%, investment in fixed assets, } \% \text {, the } \\
\text { share of foreign investment in the total investment, } \% \text {. Further, the } \\
\text { ranking of the estimates of indicators by years occurs, the most stable } \\
\text { and unstable years are determined for each of the indicators [11]. }\end{array}$ \\
\hline $\begin{array}{lr}\text { O. Prokopenko, } & \text { M. } \\
\text { Slatvinskyi, } & \text { N. } \\
\text { Biloshkurska, } & \text { M. } \\
\text { Biloshkurskyi, } & \text { V. } \\
\text { Omelyanenko } & \\
\end{array}$ & $\begin{array}{l}\text { The methodology is based on multivariate analysis of variance, } \\
\text { dependent and independent variables are selected, their impact on the } \\
\text { level of investment security is assessed [12]. }\end{array}$ \\
\hline $\begin{array}{l}\text { E.V. Korolyuk, M.G. } \\
\text { Imanova }\end{array}$ & $\begin{array}{l}\text { Safety assessment is carried out using } 4 \text { indicators: index of the } \\
\text { physical volume of GRP, \%; index of physical volume of investments } \\
\text { in fixed assets, \%; budget deficit, \% to GRP; share of the population } \\
\text { with income below the subsistence level, \%. For each of the indicators, } \\
\text { the authors have developed three threshold values depending on the } \\
\text { level of security: optimal, low, critical, the state of investment security }\end{array}$ \\
\hline
\end{tabular}




\begin{tabular}{|l|l|}
\hline & $\begin{array}{l}\text { is determined based on a comparison of the actual values of indicators } \\
\text { with the upper threshold value [13]. }\end{array}$ \\
\hline E.A. Krug & $\begin{array}{l}\text { Investment security indicators are proposed to be divided into 3 groups } \\
\text { depending on the type of risk factors (macroeconomic, mesoeconomic, } \\
\text { microeconomic). Each group of risk factors is assessed by 3 indicators. } \\
\text { The author does not provide threshold values of indicators [14]. }\end{array}$ \\
\hline M.A. Nikolaev, M.U. & $\begin{array}{l}\text { The methodology is based on the division of investment security into } \\
5 \text { components: reproduction, sectoral, innovation, quality of life and } \\
\text { Makhotaeva } \\
\text { regional. Each component is assessed using a list of indicators, for } \\
\text { each of which threshold values have been developed, based on the } \\
\text { need to ensure a positive dynamics of the resulting indicators [15]. }\end{array}$ \\
\hline $\begin{array}{l}\text { The technique is based on the use of the indicative method. The } \\
\text { assessment includes the following steps: } \\
\text { 1. Definition of research objects. } \\
\text { 2. Formation of the composition of indicative indicators for assessing } \\
\text { the level of economic security for each of the research objects. } \\
\text { 3. Collection of initial statistical data, on their basis the calculation of } \\
\text { indicative indicators. } \\
\text { 4. Formation of threshold levels (values) for indicative indicators. } \\
\text { 5. Calculation of the current values of indicative indicators for each } \\
\text { diagnosed object. } \\
\text { 6. Assessment of the state for each of the indicators when comparing } \\
\text { their current values with threshold values. The nature of the economic } \\
\text { security situation is divided into levels: normal state, pre-crisis 1 } \\
\text { (initial), pre-crisis 2 (developing), pre-crisis 3 (critical), crisis } 1 \\
\text { (unstable), crisis 2 (threatening), crisis 3 (emergency). } \\
\text { 7. Converting the values of each indicator for each object to } \\
\text { normalized index scores. } \\
\text { 8. Determination of the final state of investment security using the } \\
\text { weighted average normalized estimate[16]. }\end{array}$ \\
\hline
\end{tabular}

\section{Results}

On the basis of the presented approaches, the author's approach to assessing the investment security of the region was developed. In our opinion, monitoring of the state of financial and budgetary security should be carried out using a 100-point methodology for assessing the financial and budgetary security of the region. This methodology includes 5 main stages:

1) At the first stage, research objects are selected;

2) At the second stage, a list of indicators is formed, with the help of which the assessment is carried out, and also their threshold values are determined;

3) Further, for the studied group of regions, the actual values of the indicator are compared with the threshold values, and the safety level for each indicator is determined using a specially developed 100-point scale of normalized values;

4) At the fourth stage, using the arithmetic mean, the final score for the investment component of the financial and budgetary security of the region is calculated, based on the data obtained, the degree of danger of the actual state of the security system is determined 4

5) At the last stage, the regions are ranked according to the level of investment security, and then recommendations for eliminating the identified threats are determined.

The scores for each indicator are set in the range from 1 to 100 points using the normalizing function. To assess the level of danger, in addition to the actual threshold values, it is also proposed to calculate the upper and lower safety thresholds. The upper threshold is equal to the value of the indicator at which the maximum possible level of security is ensured, the lower threshold is the level at which security is not provided at all, it corresponds to the catastrophic state of the investment sphere. To calculate scores for indicators, the 
recommended value of which should not be less than the threshold value, the following formulas are applied:

$$
\begin{gathered}
\text { If } A \in[\text { Amin; Amax }] \\
\text { Anorm }=(A-A m i n) /(\text { Amax-Amin }) * 99+1(1) ; \\
\text { If } A>A \text { Amax; Anorm }=100(2) ; \\
\text { If } A<\text { Amin; Anorm }=1(3) ; \text { where } \\
\text { Anorm }=\text { Athreshold * } 1.25(4) ; \\
\text { Amin }=\text { Amax * 0.2 (5); } \\
\text { A - initial indicator; }
\end{gathered}
$$

Atreshold - the threshold value of the indicator.

The following formulas are used for scoring for indicators, the recommended value of which should not exceed the threshold value:

\begin{tabular}{|c|c|c|}
\hline $\mathrm{N}$ & Indicator name & $\begin{array}{l}\text { Threshold } \\
\text { value }\end{array}$ \\
\hline 1 & Fixed capital investments per capita, rubles & $\begin{array}{l}p=131631 \\
\begin{array}{l}\text { average by } \\
\text { Russia) }\end{array}\end{array}$ \\
\hline 2 & Share of investments in fixed assets in GRP, $\%$ & $p=25$ \\
\hline 3 & Ratio of investment growth rates and GRP growth rates, times & $>=2$ \\
\hline 4 & Investment growth rates in fixed assets, $\%$ & $>=8$ \\
\hline 5 & Balance of foreign direct investment per capita, $\%$ & $\begin{array}{l}>=217,84 \\
\text { (average by } \\
\text { Russia) }\end{array}$ \\
\hline 6 & Depreciation rate of fixed assets, $\%$ & $<=40$ \\
\hline 7 & $\begin{array}{l}\text { The ratio of the coefficient of renewal and disposal of fixed assets, } \\
\text { times }\end{array}$ & $>=3$ \\
\hline
\end{tabular}

$$
\begin{gathered}
\text { If } A \in[\text { Amin; Amax }] \\
\text { Anorm = (1- (Anorm-Amax }) /(\text { Amin-Amax })) * 99+1(6) ; \\
\text { If A }<\text { Amax; Anorm = } 100(7) ; \\
\text { If A }>\text { Amin; Anorm = } 1(8) ; \text { where } \\
\text { Amax }=\text { Athreshold / } 1.25(9) ; \\
\text { Amin }=\text { Athreshold / } 0.2(10) ; \\
\text { A - initial indicator; }
\end{gathered}
$$

Athreshold - the threshold value of the indicator.

The list of indicators and their threshold values for which the assessment was made is presented in table 2

Table 2. The system of indicators for the investment component of fiscal security and their threshold values

Table 4 shows the indicators required to calculate the values of indicators of the investment component of the financial security of the region. The table shows data for 2019. Data for indicators 1 and 2 were calculated for 2018, since data for 2019 have not been calculated by Rosstat.

Table 4. Indicators used to calculate investment indicators

\begin{tabular}{|c|c|c|}
\hline $\mathrm{N}$ & Index & Value \\
\hline 1 & Fixed capital investments per capita, rubles & 138886 \\
\hline 2 & GRP, million rubles & 665735.70 \\
\hline 3 & GRP physical volume index, \% & 98,5 \\
\hline 4 & Growth rates of investment in fixed assets, \% (2019) & $-16,01$ \\
\hline 5 & Growth rates of investment in fixed assets, \% (2018) & 1,73 \\
\hline 6 & Balance of direct foreign investments, USD million & -73 \\
\hline
\end{tabular}




\begin{tabular}{|l|c|c|}
\hline 7 & Depreciation rate of fixed assets, \% & 52,6 \\
\hline 8 & Fixed assets renewal ratio & 2,1 \\
\hline 9 & Fixed asset retirement rate & 0,2 \\
\hline
\end{tabular}

Based on the values presented in Table 4, the values of the indicators of the investment component of the financial security of the Komi Republic were calculated and also the scores for each of the indicators. Using the arithmetic mean of the estimates obtained, the value of the final indicator was calculated, showing the level of investment security of the Komi Republic.

Table 5. Assessment of investment security of the Komi Republic

\begin{tabular}{|lllllllll|}
\hline \multicolumn{7}{c|}{ Investment security Indicators } \\
\hline $\mathrm{N}$ & 1 & 2 & 3 & 4 & 5 & 6 & 7 & Final score \\
\hline $\begin{array}{l}\text { Threshold } \\
\text { value }\end{array}$ & 131631 & 25 & 2 & 8 & 217,84 & 40 & 3 & 75 \\
\hline $\begin{array}{l}\text { Upper } \\
\text { threshold } \\
\text { value }\end{array}$ & 164538,75 & 31,25 & 2,5 & 10 & 272,3 & 50 & 3,75 & 100 \\
\hline $\begin{array}{l}\text { Lower } \\
\text { threshold } \\
\text { value }\end{array}$ & 32907,75 & 6,25 & 0,5 & 2 & 54,46 & 10 & 0,75 & 1 \\
\hline $\begin{array}{l}\text { Indicator } \\
\text { value }\end{array}$ & 138886 & 20,5 & 1,03 & $-16,01$ & $-87,93$ & 52,6 & 10,5 & 42 \\
\hline Score & 35 & 57 & 27 & 1 & 1 & 70 & 100 & 42 \\
\hline
\end{tabular}

At the last stage of the assessment, the regions are divided into safety zones in accordance with the assigned points. In general, six security zones can be distinguished.

Table 6. Compliance of the final score to the level of investment security

\begin{tabular}{|l|l|}
\hline Level of security & Score \\
\hline High level of security & $81-100$ \\
\hline Stability & $75-80$ \\
\hline Minor hazard & $60-74$ \\
\hline High danger & $40-59$ \\
\hline Crisis & $20-39$ \\
\hline Catastrophic condition & $1-19$ \\
\hline
\end{tabular}

\section{Discussion}

Thus, based on the analysis performed, it should be summarized that the final indicator of investment security of the Komi Republic corresponds to the zone of significant danger, only for one indicator "the correlation of the ratio of renewal and retirement of fixed assets" the region received the highest score. At the same time, the data on the indicators "growth rates of investments in fixed assets" and "the ratio of investment growth rates and GRP growth rates, times" indicate a catastrophic decline in investment in the real economy; at present, the level of investment activity in the region is extremely low.

Another threat to financial security is the outflow of capital abroad, which was diagnosed when analyzing the indicator "Balance of foreign direct investment per capita", this problem is typical not only for the Komi Republic, but also for such regions of the North-West Federal districts such as Arkhangelsk Region, the Nenets Autonomous Okrug, the Leningrad Region and the city of St. Petersburg. In addition, a low level of security was also noted. In general, the problem of lack of investment is typical not only for the Komi Republic, but also for 
many other regions of the Northwestern Federal District. A decrease in the volume of investments is observed in most regions. This problem poses a significant threat to the transformation of the northern regions of the country into the raw material bases of Russia, which are currently deprived of prospects for development.

The threat of a lack of investment in the region's economy is also confirmed by the low assessment of the indicator "investment in fixed assets per capita, rubles", which corresponds to the crisis level of investment security. Lack of investment leads to a decrease in economic and entrepreneurial activity in the region, and a decrease in production and population. In the past thirty years, there has been a significant migration in the Republic to the more southern regions, as well as to Moscow and St. Petersburg. According to Rosstat data, over the past thirty years, the population of the republic has decreased in the Komi Republic over the past three decades, according to Rosstat data, the population has decreased by more than 1.5 times, if in 1989 there were 1261024 people living in the region, then by January 2021 the number of inhabitants of the republic decreased to 813859 people, while according to statistics of January 1, 2020, in 22 out of 23 settlements of the republic with a population of more than 5 thousand people, a decrease in the population was observed, including in the capital of the republic, the city of Syktyvkar. A high threat is also posed by the threat of a decrease in the share of investments in the region's GRP was diagnosed during the assessment.

In our opinion, the existing problems of economic development cannot be solved in a short time, a necessary condition for the development of the region is the development of both tactical and strategic measures to bring the region out of the crisis, it is necessary to conduct a policy in the region aimed at diversifying the economy, it is necessary to create special economic zones of industrial-production type, which can significantly increase the investment attractiveness of the region, it is necessary to open new manufacturing enterprises, improve conditions for small and medium-sized businesses. One of the measures to stimulate the development of entrepreneurship may be the expansion of the practice of tax incentives for newly opened enterprises, as well as the provision of preferential loans for starting a business. It seems necessary to adopt at the level of the republic a Strategy for the investment development of the region which would provide specific steps and measures to develop the economy of the republic.

\section{Conclusions}

The feasibility and effectiveness of the proposed methodology for assessing the investment component of financial and budgetary security was confirmed by calculating the indicators of the Komi Republic. Based on a comparison of the actual values of indicators with threshold values, maximum threshold values and minimum threshold values, a point assessment of the investment component of the region's financial security was carried out. As a result, it was revealed that the Komi Republic is in a zone of significant danger. Significant threats to investment security have been identified, they include a decrease in investment, insufficient investment in the real economy, capital outflow from the region. Only 1 out of 7 indicators correspondent to the threshold level. Such assessment shows necessity of taking consistent and effective tactical and strategic measures to increase the investment attractiveness of the region. The developed methodology can be used by federal and regional authorities in order to carry out a timely assessment of the existing threats to the investment sphere of the region, which will make it possible to take timely measures to eliminate them and prevent consequences that have a negative impact on the development of the regional economy. 


\section{References}

1. O.V. Fedonina, Naukovedenie, 8(2), 1 (2016)

2. E.A. Shutaeva, V.V. Pobirchenko, National Interests: Priorities and Security, 14(8), 1498 (2018)

3. V.P. Chichkanov, L. A. Belyaevskaya-Plotnik, Economy of Region, 14(1), 227 (2018)

4. E. Karanina, M. Kyzyurov, S. Chuchkalova, E3S Web of Conferences: Topical Problems of Green Architecture, Civil and Environmental Engineering 2019 (TPACEE-2019), 164, 09030 (2020)

5. E. Karanina, M. Kyzyurov, E3S Web of Conferences (ERSME-2020), 217, 07013 (2020)

6. N.K. Ismailova, International Journal of Humanities and Natural Sciences, 5-4, 122 (2019)

7. D. Loginov, E. Karanina, SPbWOSCE-2018 E3S Web of Conferences, 110, 02021 (2019)

8. L. Karpenko, O. Ignatenko, O. Taranenko, I. Oliinyk, R. Khrenova-Shymkina, Entrepreneurship and sustainability issues, 8(3), 367 (2021)

9. M.G Nikitina, V.V. Pobirchenko, E.A. Shutaieva, A.I. Karlova, Entrepreneurship and sustainability issues, 8(2), 958 (2018)

10. O. Prokopenko, M. Slatvinskyi, N. Biloshkurska, M. Biloshkurskyi, V. Omelyanenko, Problems and Perspectives in Management, 17(1), 380 (2019)

11. E.V. Korolyuk, M.G. Imanova, Kant, 4(37), 124 (2020)

12. E.A. Krug Vestnik Moscow city university scientific Journal, series Economics, 1(23), $8(2020)$

13. M.A. Nikolaev, M.U. Makhotaeva St. Petersburg state polytechnic university journal economics, 10(5), 34 (2017)

14. M.V. Vlasov, Bulletin of Ural Federal University. Series Economics and Management, 18(4), 556 (2019) 